\title{
Introduction to Practice Matters Special Section on the Rorschach
}

\author{
F. Barton Evans
}

Received: 1 October 2012 / Accepted: 1 October 2012 / Published online: 24 October 2012

(C) Springer Science+Business Media New York 2012

It is with great pleasure that I introduce the Psychological Injury and the Law (PIL) Special Section on the Rorschach and especially the Rorschach Performance Assessment System (R-PAS; Meyer, Viglione, Mihura, Erard, \& Erdberg, 2011). Numerous surveys have indicated that the Rorschach is one of the most widely used psychological tests in clinical and forensic practice (Archer, BuffingtonVollum, Stredny, \& Handel, 2006; Camara, Nathan, \& Puente, 2000; Norcross \& Karpiak, 2012), including in psychological injury evaluations (Boccaccini \& Brodsky, 1999). While there have been numerous Rorschach systems (Exner, 1969), it is widely understood that, until recently, the Exner Comprehensive System (CS, Exner, 2003) was the only system with sufficient reliability and validity to be used in forensic settings (see Gacono, Evans, \& Viglione, 2008).

Yet, in recent years, a small group of critics (e.g., Lilienfeld, Wood, \& Garb, 2000) have raised questions about the validity of the Rorschach and have gone as far as taking the unprecedented step of calling for a "moratorium" on its use in clinical and forensic practice (Garb, 1999). These harsh critiques rest on a general misunderstanding of clinical and forensic practice and, not infrequently, a misrepresentation of the empirical literature (see Gacono \& Evans, 2008 for a comprehensive treatment of

\author{
F. B. Evans \\ Clinical \& Forensic Psychologist, \\ Asheville, NC, USA \\ F. B. Evans \\ Psychiatry and Behavioral Sciences, \\ George Washington University School of Medicine, \\ Washington DC, USA \\ F. B. Evans $(\bowtie)$ \\ 113 College Circle, \\ Swannanoa, NC 28778, USA \\ e-mail: fbevans3@gmail.com
}

the scientific, legal, and clinical foundations of the Rorschach in forensic practice and Evans (2008) on the admissibility of the CS Rorschach). A positive outcome of this often-contentious debate has been an increase in research on the Rorschach, the best of which is well represented in the articles in this Special Section and the development of the R-PAS.

The Special Section opens with Joni Mihura's discussion of the role of the Rorschach in comprehensive multi-method psychological assessment, the core of good forensic practice. Her analysis cogently argues for the incremental validity of performance-based measures over and above self-report measures such as the MMPI. Her argument is significantly advanced by her rather modest reference to her groundbreaking metaanalysis of main Rorschach variables (Mihura, Meyer, Dumitrascu, \& Bombel, 2012), which forms the empirical backbone of the R-PAS. In this author's opinion, the meta-analysis by Mihura et al. (2012) is the most important empirical advance in Rorschach research since Exner's original publication of the CS (Exner, 1974).

Next up is Gregory Meyer and Josh Eblin's systematic and thorough overview of the R-PAS, the newest Rorschach system and the only system other than the CS with a comprehensive and well-researched empirical base. This introduction to the R-PAS provides a summary of the evolution and scientific foundation of this exciting development in Rorschach assessment. The authors discuss the progress of the R-PAS beyond the CS and offer the R-PAS as the next generation, empirically supported Rorschach assessment. Their arguments are compelling and seasoned forensic psychologists should carefully consider the R-PAS for adoption based on empirical sturdiness.

With the scientific foundation of the R-PAS now well covered, what follows is Robert Erard's carefully reasoned article on the use of R-PAS for forensic consultation and expert testimony in psychological injury cases. Erard 
argues that the R-PAS more than meets admissibility standards when it is appropriately used. He provides clear guidelines on how to best represent the R-PAS's considerable value in forensic assessment in psychological injury. Erard cogently argues for the R-PAS as the next generation Rorschach system designed with strong empirical foundation necessary for admissibility as a forensic psychological assessment.

The fourth original article is this Special Section is Donald J. Viglione, Benjamin Towns, \& Dawn Lindshield's review of the Rorschach's capability to assess post-traumatic conditions. Here, Viglione and his colleagues draw upon his vast knowledge of the empirical foundations of the Rorschach CS to provide a creative interplay between research and a conceptual understanding of how PTSD "lives" on the Rorschach. Their approach incorporates primarily CS based research, which is readily applicable to the R-PAS, and presents an "experience near" understanding of how the tortured inner world of the trauma survivor comes alive on the Rorschach.

The last article is the Special Section is the article by Khadivi and Evans, which offers their thoughts on the strengths and challenges of the R-PAS. This commentary is offered in the spirit of collaborative critique, which has spurred much thoughtful research leading to the growth of Rorschach assessment.

In closing, the Special Section on the Rorschach provides a comprehensive introduction to the exciting new developments in Rorschach assessment that offers the forensic psychological assessor with a complementary strategy to selfreport inventories. Though not yet proven in the forensic arena, the R-PAS is an exciting development in both clinical and forensic practice and offers psychological injury assessors an additional strategy in providing comprehensive, multimethod assessment.

\section{References}

Archer, R. P., Buffington-Vollum, J. K., Stredny, R. V. \& Handel, R. W. (2006). A survey of psychological test use patterns among forensic psychologists. Journal of Personality Assessment, 87, 84-94.

Boccaccini, M. T. \& Brodsky, S. L. (1999). Diagnostic test use by forensic psychologists in emotional injury cases. Professional Psychology: Research and Practice, 30, 253-259.

Camara, W. J., Nathan, J. S. \& Puente, A. E. (2000). Psychological test usage: Implications in professional psychology. Professional Psychology: Research and Practice, 31, 141-154.

Evans, F. B., III. (2008). Admissibility of the Rorschach in court: An update. In C. B. Gacono \& F. B. Evans (Eds.), The Handbook of Forensic Rorschach Assessment. New York: Routledge.

Exner, J. E. (1969). The Rorschach systems. New York: Grune \& Stratton.

Exner, J. E. (1974). The Rorschach: A comprehensive system. New York: Wiley.

Exner, J. E. (2003). The Rorschach: A comprehensive system (4th ed.). New York: Wiley.

C. B. Gacono \& F. B. Evans, (Eds.), (with N. Kaser-Boyd, \& L. A. Gacono) (Col). (2008). The handbook of forensic Rorschach assessment (pp. 89-119). New York, NY: Routledge

Gacono, C. B., Evans, F. B. \& Viglione, D. (2008b). Essential issues in the forensic use of the Rorschach. In C. B. Gacono \& F. B. Evans (Eds.), The handbook of forensic Rorschach assessment (pp. 320). New York: Routledge.

Garb, H. N. (1999). Call for a moratorium on the use of the Rorschach inkblot test in clinical and forensic settings. Assessment, 6, 313317.

Lilienfeld, S. O., Wood, J. M. \& Garb, H. N. (2000). The scientific status of projective techniques. Psychological Science in the Public Interest, 1, 27-66.

Meyer, G. J., Viglione, D. J., Mihura, J. L., Erard, R. E. \& Erdberg, P. (2011). Rorschach performance assessment system: Administration, coding, interpretation, and technical manual. Toledo: Author.

Mihura, J. L., Meyer, G. J., Dumitrascu, N. \& Bombel, G. (2012). The validity of individual Rorschach variables: Systematic reviews and meta-analyses of the comprehensive system. Psychological Bulletin. doi:10.1037/a0029406

Norcross, J. C. \& Karpiak, C. P. (2012). Clinical psychologists in the 2010s: 50 years of the APA Division of Clinical Psychology. Clinical Psychology: Science and Practice, 19, 1-12. 